\title{
MEIS3 is repressed in A549 lung epithelial cells by deoxynivalenol and the repression contributes to the deleterious effect
}

\author{
Takahito Toyotome ${ }^{1,3}$, Hiroki Takahashi² and Katsuhiko Kamei ${ }^{3}$ \\ ${ }^{1}$ Research Unit for Risk Analysis, Diagnostic Center for Animal Health and Food Safety, \\ Obihiro University of Agriculture and Veterinary Medicine, Nishi 2-11, Inadacho, Obihiro, Hokkaido, 080-8555, Japan \\ 2Division of Bio-resources, Medical Mycology Research Center, Chiba University, \\ 1-8-1 Inohana, Chuo-ku, Chiba City, Chiba, 260-8673, Japan, \\ ${ }^{3}$ Division of Clinical Research, Medical Mycology Research Center, Chiba University, \\ 1-8-1 Inohana, Chuo-ku, Chiba City, Chiba, 260-8673, Japan
}

(Received July 17, 2015; Accepted October 18, 2015)

\begin{abstract}
Deoxynivalenol (DON) is an important Fusarium toxin of concern for food safety. The inhalation of powder contaminated with DON is possible and may cause lung toxicity. In this study, we analyzed the gene expression profile of A549 cells treated for $24 \mathrm{hr}$ with $0.2 \mu \mathrm{g} / \mathrm{mL}$ DON by microarray analysis. In total, 16 genes and 5 noncoding RNAs were significantly affected by DON treatment. The repression of B3GALT4, MEIS3, AK7, SEMA3A, KCNMB4, and SCARA 5 was confirmed by quantitative PCR. We investigated the DON toxicity on A549 cells that exogenously expressed these 6 genes. The result indicated that A549 cells that transiently expressed MEIS3 were tolerant to the deleterious effects of DON. Our data show that DON affected the expression of genes with various functions, and suggest that the repression of MEIS3 plays roles in the deleterious effect of DON in A549 lung epithelial cells.
\end{abstract}

Key words: Fusarium toxin, Mycotoxin, Deoxynivalenol, Trichothecene, Lung epithelial cell

\section{INTRODUCTION}

Deoxynivalenol (DON) is produced by several Fusarium spp., primarily F. graminearum, and is a member of the trichothecenes. Trichothecenes include more than 200 compounds and are among the important mycotoxins of concern for food safety. Wet and cold weather crops, including wheat, corn, and other cereals, are more susceptible to infection by trichothecene-producing fungi in the field, whereby infected grains are contaminated with trichothecenes. Trichothecenes affect weight gain and the gastrointestinal, neuroendocrine, and immune systems of humans and animals (Food Safety Commission of Japan, 2010). Although two other trichothecenes, T-2 and HT-2, are also important for food safety, DON is more frequently found in cereal grains than T-2 and HT-2 toxin (Food Safety Commission of Japan, 2010; Schothorst and van Egmond, 2004).

Grain dust is a complex mixture of materials, including fungi and fungal products. Spankie and Cherrie
(2012) examined workers' exposure to inhalable grain dust in Great Britain and estimated that the average 8-hr personal exposure levels were less than approximately $3 \mathrm{mg} / \mathrm{m}^{3}$, although perhaps 5\%-20\% of individual personal exposures were still more than $100 \mathrm{mg} / \mathrm{m}^{3}$. Importantly, trichothecenes and other mycotoxins have been detected in airborne dusts from farms and agricultural workspaces, respectively (Brera et al., 2002; Halstensen, 2006; Nordby, 2004). These reports suggest that the inhalation of grain powder and dust containing DON is possible and may cause lung toxicity. Acute toxicity after T-2 inhalation has been reported by Creasia et al. $(1987,1990)$ and Pang et al. $(1987,1988)$; however, the toxicity of DON has not been examined. Recently, Amuzie et al. (2008) have reported DON concentrations in blood and tissues as well as proinflammatory cytokine induction by DON administered via the intranasal route in mice. In their report, DON concentrations in blood and tissues of mice exposed via the intranasal route were significantly higher than those in blood and tissues of mice exposed via the oral route, sug-

Correspondence: Takahito Toyotome (E-mail: tome@obihiro.ac.jp) 
gesting that the toxic effect of DON is stronger on nasally exposed mice than on orally exposed mice. The toxicity of DON to mammalian cells has been examined. DON is cytotoxic to various cell lines, including a Chinese hamster lung fibroblast cell line, V-79 (Behm et al., 2012; Cetin and Bullerman, 2005), and human cell lines, including the human lung epithelial cell line A549 (Nielsen et al., 2009). However, the mechanism underlying the toxicity of DON to A549 cells remains unknown.

In this study, we examined the gene expression in A549 lung epithelial cells, and found that 6 genes, including MEIS3, were repressed by DON treatment. MEIS3 is a transcription factor of three-amino-acid-loop-extension (TALE) homeodomain protein. Meis 3 in Xenopus plays an important role in hindbrain development. Liu et al. (2010) have reported that Meis 3 is expressed in mouse $\beta$-cells and regulates survival in $\beta$-cells. A549 cells that transiently expressed MEIS3 were tolerant to the deleterious effects of DON. Our data show that DON affected the expression of genes with various functions, and suggest that the repression of MEIS3 plays roles in the deleterious effect of DON in A549 lung epithelial cells.

\section{MATERIALS AND METHODS}

\section{Reagents}

DON (Sigma-Aldrich Co., St. Louis, MO, USA) was dissolved in saline and stored at $-20^{\circ} \mathrm{C}$. z-VAD-fmk, a pan-caspase inhibitor, was purchased from Peptide Institute, Inc. (Osaka, Japan), and used at $50 \mu \mathrm{M}$. z-VADfmk treatment was started at $30 \mathrm{~min}$ before DON treatment. To amplify B3GALT4, MEIS3, AK7, SEMA3A, $K C N M B 4$, and $S C A R A 5$, we used primers listed in Supplementary Table 1 and PrimeScript II High Fidelity One Step RT-PCR Kit (Takara Bio Inc., Osaka, Japan). To amplify vector fragment of p3×FLAG-CMV-14

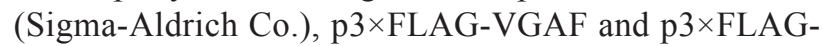
VGAR primers (Supplementary Table 1) and Q5 Hot Start High-Fidelity $2 \times$ Master Mix were used (New England Biolabs, Ipswich, MA, USA). To clone these genes into p3×FLAG-CMV-14, Gibson Assembly Cloning Kit (New England Biolabs) was used.

\section{Cell line and growth condition}

The lung epithelial cell line A549 derived from human lung adenocarcinoma was grown at $37^{\circ} \mathrm{C}$ in Dulbecco's Modified Eagle Medium containing $4.5 \mathrm{~g} / \mathrm{L}$ glucose and supplemented with $5.958 \mathrm{~g} / \mathrm{L}$ HEPES, $0.584 \mathrm{~g} / \mathrm{L}$ L-glutamine, and $0.0159 \mathrm{~g} / \mathrm{L}$ phenol red in the presence of $5 \% \mathrm{CO}_{2}$.

\section{Cell counting assay}

To determine the number of living cells after treatment with DON for 24 or $48 \mathrm{hr}$, we used the Cell Counting Kit-8 (Dojindo Laboratories, Kumamoto, Japan) according to the manufacturer's instructions. A549 cells $\left(5 \times 10^{3}\right)$ were seeded and grown in media for $24 \mathrm{hr}$, various concentrations $(0.05,0.1,0.2,0.4,0.8,1.6,3.1,6.3$, 12.5 , and $25 \mu \mathrm{g} / \mathrm{mL}$ ) of DON were added, and the cells were cultured for $24 \mathrm{hr}$ or $48 \mathrm{hr}$. Cell counting kit solution $(10 \mu \mathrm{L})$ was added to each well, and after incubation for $1 \mathrm{hr}$, absorbance at $450 \mathrm{~nm}$ was determined using a Genios Pro absorbance reader (Tecan, Männedorf, Switzerland). The half-maximal inhibitory concentration $\left(\mathrm{IC}_{50}\right)$ of DON with regard to the proliferation of A549 cells was determined from the data by fitting to a 4-parameter logistic curve using Image J ver. 1.48 (Rasband, W.S., ImageJ, U. S. National Institutes of Health, Bethesda, MD, USA; http://imagej.nih.gov/ij/, 1997-2014). For the assay under a confluent culture, A549 cells seeded at $5 \times 10^{4}$ cells and then cultured for $24 \mathrm{hr}$ were treated with DON for $96 \mathrm{hr}$.

\section{Total RNA preparation and microarray analysis}

This analysis involved the same conditions as those for the cell counting assay, except for the DON concentrations. A549 cells were treated with $0.2 \mu \mathrm{g} / \mathrm{mL}$ DON for $24 \mathrm{hr}$. Two total RNA samples from A549 cells were treated with DON (two samples were treated, while two were not). These four samples were recovered by TRIReagent using the Direct-zol RNA MiniPrep Kit purchased from Zymo Research Corp. (Irvine, CA, USA). Each RNA integrity number (RIN) (Imbeaud et al., 2005; Schroeder et al., 2006) was determined by Agilent 2100 Bioanalyzer (Agilent Technologies, Inc., Santa Clara, CA, USA). The RIN numbers of the four samples were more than 9.5 (data not shown). The samples were analyzed on SurePrint G3 Human 8x10K ver. 2.0 (Agilent Technologies, Inc.), and raw data were normalized using GeneSpring GX software (Agilent Technologies, Inc.) by Hokkaido System Science Co., Ltd. (Hokkaido, Japan). The data were submitted to the Gene Expression Omnibus database at the National Center for Biotechnology Information (GEO: GSE60928). The threshold used to judge whether a probe expressed in a particular experiment was set to the median value of a data set. Of 61,657 probes, 32,710 probes with intensities were higher than the median values in at least one experiment were selected. The logarithmic ratio of expression intensity between two controls and two DON-treated samples was calculated and tested using Student's t-test, and the $p$-values were corrected using the false discovery rate (FDR) method 
The expression and the role of MEIS3 in A549 cell on DON treatment

(Benjamini and Hochberg, 1995). Using the thresholds of 2 - or 0.5 -fold and the FDR-corrected $p$-value $(p \leq 0.05)$, 134 probes were significantly exchanged in our experiment. Of those, the FDR corrected $p$-values of 21 probes were less than 0.01 .

\section{Quantitation of gene expression by real-time quantitative polymerase chain reaction}

Total RNA samples were prepared as described above or using the SuperPrep Cell Lysis Kit for quantitative PCR (qPCR) (Toyobo Co., Ltd., Osaka, Japan). For cDNA synthesis, we used the RT Kit (Toyobo) optimized for lysate by the SuperPrep Cell Lysis Kit or we used ReverTra Ace qPCR RT Master Mix with the gDNA Remover kit (Toyobo). For real-time qPCR, THUNDERBIRD SYBR qPCR Mix (Toyobo) was used. Primers used for qPCR are listed in Supplementary Table 1. LightCycler 480 (Roche Diagnostics, Basel, Switzerland) was used for real-time PCR. Each Crossing Point was determined using the second derivative maximum method, and the Pfaffl method was used for relative quantification (Pfaffl, 2001). For the quantification, we used the $\beta$-actin gene as a housekeeping gene for reference.

\section{Transfection}

Avalanche-Omni Transfection Reagent (EZ Biosystems LLC, College Park, MD, USA) was used for transfection. $0.1 \mu \mathrm{g}$ of plasmids were used for each $10 \mu \mathrm{L}$ transfection mixture. A549 cells were seeded at $2.5 \times 10^{3}$ or $5 \times 10^{4}$ cells in $100 \mu \mathrm{L}$, and transfection mixture was added to cells on the following day. After transfection for $24 \mathrm{hr}$, DON was treated as described above.

\section{RESULTS}

\section{Twenty-one genes and noncoding RNAs are extracted as their expression is significantly changed by DON treatment}

We performed microarray analysis to investigate the expression profile after treatment with DON and determine the genes and noncoding RNAs repressed or induced by DON. Prior to the analysis, A549 cells were exposed to various concentrations of DON. The number of A549 cells treated with 0.5 or $2.5 \mu \mathrm{g} / \mathrm{mL} \mathrm{DON} \mathrm{for}$ $24 \mathrm{hr}, 48 \mathrm{hr}$, and $72 \mathrm{hr}$ was lower than the number of nontreated cells (Fig. 1A and Supplementary Fig. 1). The estimated $\mathrm{IC}_{50}$ of DON with regard to the growth of A549 cells after $48 \mathrm{hr}$ of treatment was $0.52 \mu \mathrm{g} / \mathrm{mL}$ (Fig. 1B). We set the DON concentration for microarray analysis at $0.2 \mu \mathrm{g} / \mathrm{mL}$, because at this concentration the proliferation of A549 cells was not significantly inhibited by DON
( $p>0.01$, compared with nontreated cells by Student's $t$-test). The microarray analysis shows that compared with nontreated A549 cells, the expression of 16 genes and 5 noncoding RNAs was significantly changed in A549 cells treated with $0.2 \mu \mathrm{g} / \mathrm{mL}$ DON (Supplementary Table 2). These data suggest that DON has effects on the expression of these genes and noncoding RNAs in the A549 cells.

\section{Quantitative PCR analysis confirms that 8 genes change their expression after treatment with DON}

To confirm the expression of 16 genes in A549 cells extracted by microarray analysis, we examined their expression by qPCR after treatment with DON at 0.1 , 0.5 , and $2.5 \mu \mathrm{g} / \mathrm{mL}$. Because the increases of $H M O X 1$ and $S M O X$ expression by DON treatment were repeatedly detected in microarray data, we included $H M O X 1$ and $S M O X$ in the quantification. Nine genes were amplified and quantified by the primers listed in Supplementary Table 1. The expression of B3GALT4, MEIS3, AK7, $S E M A 3 A, K C N M B 4$, and SCARA5 was decreased by DON treatment, although no change in the expression of TLR1 was detected (Fig. 2 and Supplementary Table 3). The expressions of $H M O X 1$ and $S M O X$ were induced by DON treatment. The data show that the expression of these 8 genes was changed by DON treatment.

\section{The expression of MEIS3 tolerates DON toxicity}

We examined the effect of exogenous expression of B3GALT4, MEIS3, AK7, SEMA3A, KCNMB4, and $S C A R A 5$ genes in A549 cells on DON treatment, revealing that MEIS3-transfected cells were tolerant to DON treatment (Fig. 3 and Supplementary Fig. 2). These data indicate that MEIS3 partially plays a role in the deleterious effect of DON.

\section{DISCUSSION}

In this study, we analyzed the expression profile of A549 lung epithelial cell after DON treatment. Our microarray and qPCR analyses revealed that the expression of B3GALT4, MEIS3, AK7, SEMA3A, and KCNMB4 in A549 cells was decreased by DON treatment. In addition, A549 cell transiently expressed MEIS3 was tolerant to the deleterious effect of DON. These data suggest that DON represses MEIS3 expression and contributes to the deleterious effect of DON.

The deleterious effect of DON shown in Fig. 1 was partially rescued by the treatment with z-VAD-fmk pancaspase inhibitor (data not shown), indicating that cas- 
A
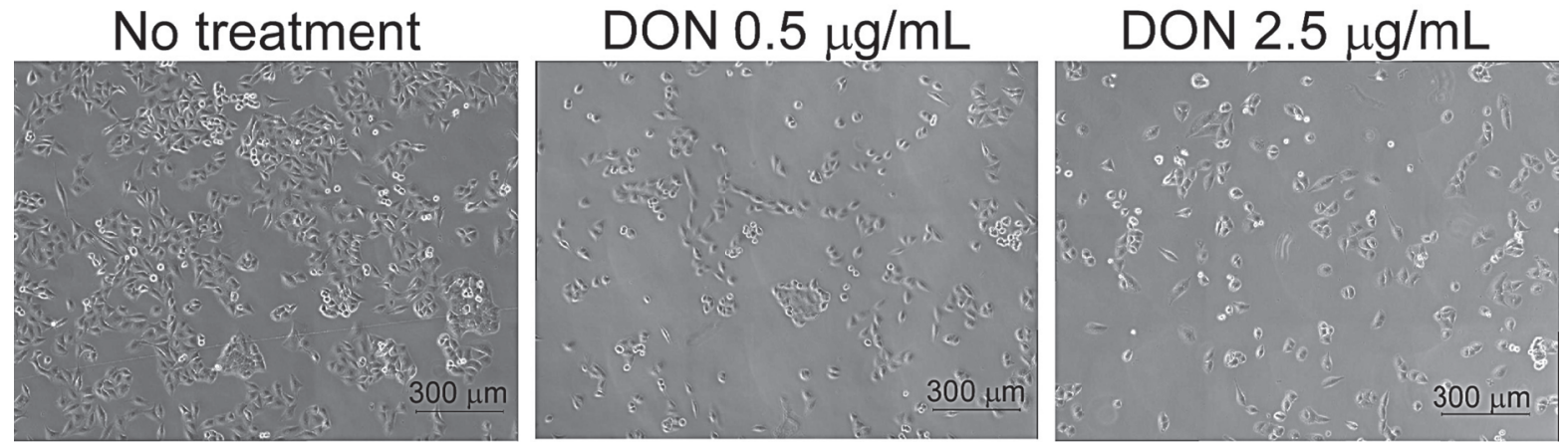

B

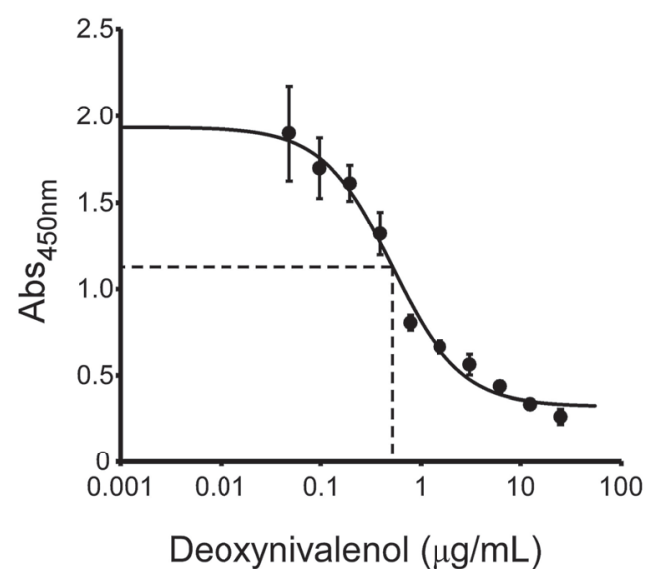

Fig. 1. A549 cells were affected by DON. (A) A549 cells not treated (left) or treated with DON at the concentration of $0.5 \mu \mathrm{g} / \mathrm{mL}$ (middle) or $2.5 \mu \mathrm{g} / \mathrm{mL}$ (right) for $24 \mathrm{hr}$. (B) The result of cell counting assay on A549 cells treated with DON for $48 \mathrm{hr}$. $x$ - and $y$-axes indicate the absorbance at $450 \mathrm{~nm}$ and treated DON concentration, respectively. Filled circles and error bars indicate averages and standard deviations of absorbance calculated from 4 independent wells, respectively. The curve indicates a 4-parameter logistic curve fitted from our data.

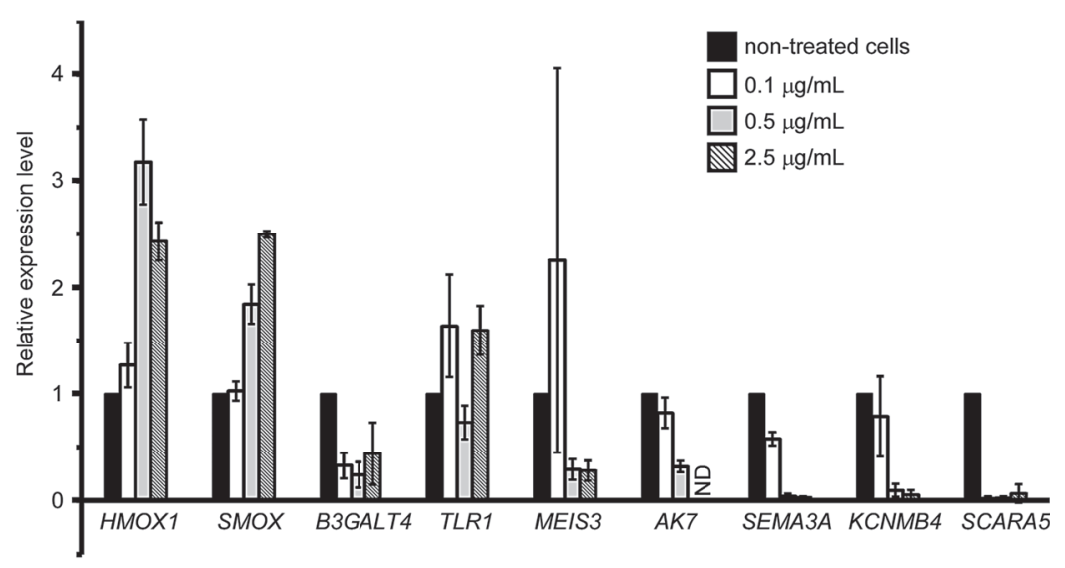

Fig. 2. Expression levels of 9 genes in DON-treated cells compared with those in non-treated cells. Bars indicate the expression in nontreated cells (filled bars) and in cells treated with $0.1 \mu \mathrm{g} / \mathrm{mL}$ (open white bars), $0.5 \mu \mathrm{g} / \mathrm{mL}$ (grey bars), and $2.5 \mathrm{mg} / \mathrm{mL}$ (hatched bars) DON. ND: not detected. 
The expression and the role of MEIS3 in A549 cell on DON treatment

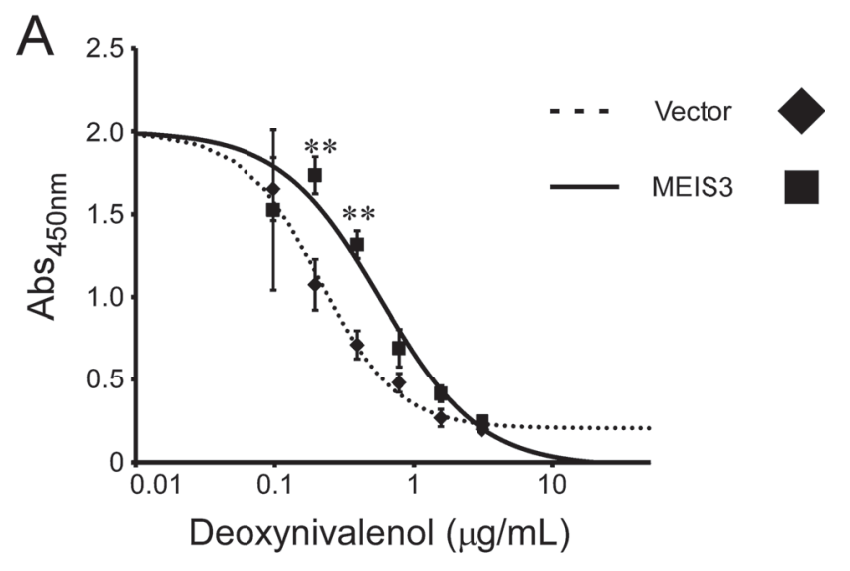

B

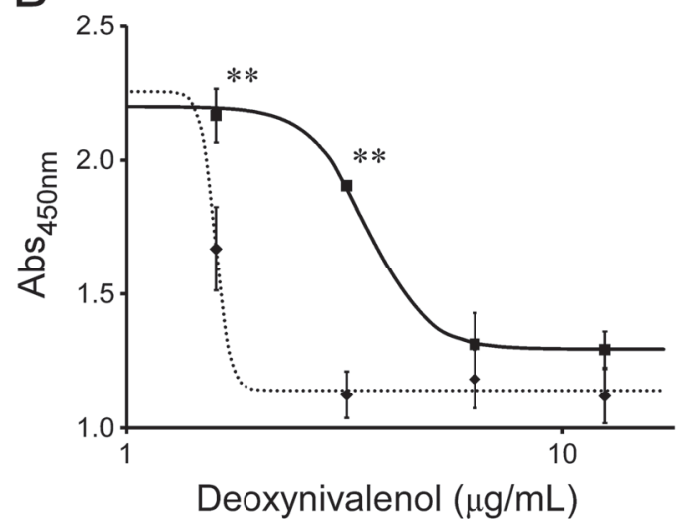

Fig. 3. MEIS3 tolerated DON deleterious effect. Under the low confluent condition (A) or the confluent condition (B), MEIS3-expressed cells were partially resistant to the deleterious effect of DON. The results of cell counting assay on A549 cells treated with DON for $48 \mathrm{hr}(\mathrm{A})$ or $96 \mathrm{hr}(\mathrm{B}) . x$ - and $y$-axes indicate the absorbance at $450 \mathrm{~nm}$ and treated DON concentration, respectively. Filled circles and error bars indicate averages and standard deviations of absorbance calculated from 3 independent wells, respectively. The curves indicate 4-parameter logistic curves fitted from our data. Solid lines: Curve for A549 cells transfected with empty vector. Dotted lines: Curve for MEIS3-transfected cells. ${ }^{* *}: \mathrm{p}<0.01$, Student's $t$-test.

pase-related apoptosis included the DON deleterious effect. Liu et al. (2010) indicated that Meis 3 regulated the survival in mouse $\beta$-cells and Meis3 repression induced caspase activation and apoptosis. Meis 3 repression by silencing induced caspase activation and apoptosis, and PDK1 overexpression partially rescued the apoptosis in Meis3-deficient cells (Liu et al., 2010). Our data suggest that MEIS3 repression by DON was triggered caspase-related apoptosis. Because our microarray data show that the expression of PDK1 in DON-treated A549 cells was not significantly changed compared with untreated cells, other pathways may induce cell death by DON treatment. Because the mechanisms of MEIS3 repression by DON and apoptosis induction by MEIS3 are unknown, further examination is warranted.

Our microarray analysis revealed that the expression of B3GALT4, AK7, SEMA3A, and KCNMB4 in A549 cells was also decreased by DON treatment. B3GALT4 encodes UDP-galactose: $\beta$-N-acetyl-galactosamine $\beta-1,3-$ galactosyltransferase (Amado et al., 1998) and its expression has been detected in the lung (Shiina et al., 2000). This protein is important for the synthesis of the ganglioside GM1a/GD1b/GT1c (Guimaraes et al., 2011; Maccioni et al., 2011). Kralj et al. (2007) reported that trichothecenes induced the accumulation of glucosylceramide by interfering with lactosylceramide synthase and reduced the amount of lactosylceramide and gangliosides. Although the reduction of gangliosides, including GM1a/ GD1b/GT1c, results from the inhibition of lactosylceramide synthase, the decrease in B3GALT4 expression may additively reduce these gangliosides. Dong et al. (2010) reported that B3GALT4 expression in melanoma cells by transfection reduced tumour phenotypes, including cell growth and invasion. The expression of B3GALT4 in DON-treated cells was decreased; therefore, other roles of decreased GM1a/GD1b/GT1c may be involved in the inhibition of cell proliferation by DON. $A K 7$ encodes adenylate kinase 7 , which is linked to primary ciliary dyskinesia. Although the expression of $A K 7$ has only been detected in the descending airways and respiratory epithelium of the trachea and not in the alveolar epithelium (Fernandez-Gonzalez et al., 2009), inhaled DON may decrease the $A K 7$ expression of and affect the ciliary beat frequency. SEMA3A encodes semaphorin $3 \mathrm{~A}$, and it is also detected in the lung, where it plays important roles in distal pulmonary epithelia differentiation and lung morphogenesis (Becker et al., 2011). Interestingly, TUNELpositive cells were significantly enhanced in alveoli from SEMA3A knockout mice, and it was suggested that the loss of SEMA3A signalling temporarily regulates cell death (Becker et al., 2011). A small number of apoptotic-like A549 cells were observed when treated with high concentrations of DON; therefore, SEMA3A reduction may contribute to cell death. $K C N M B 4$ encodes a largeconductance, $\mathrm{Ca}^{2+}$-activated, voltage-dependent $\mathrm{K}^{+}(\mathrm{BK})$ channel $\beta 4$ subunit that is prominently expressed in the brain and is also expressed in the lung (Brenner et al., 2000). Although the expression of KCNMB4 in airway epithelial cells is downregulated by interferon- $\gamma$ treatment (Manzanares et al., 2014), the role of KCNMB4 has 
not been elucidated in the lung. Recently, Weigner et al. (2000) and Shruti et al. (2012) reported that KCNMB4 reduces the activity and surface presentation of the $\mathrm{BK}$ channel. Although our data do not support the reduction of $K C N M B 4$ in the brain, DON may affect the expression of $K C N M B 4$ and the activity of the BK channel in the brain. SCARA5 encodes a class A scavenger receptor (Jiang et al., 2006) that binds to ferritin and plays a role in iron delivery (Li et al., 2009). Recently, Liu et al. (2013) have shown that SCARA5 in A549 cells plays an important role in epithelial-to-mesenchymal transition. The contribution of reduced SCARA5 to DON toxicity remains unknown. Therefore, we will examine the epithelial-to-mesenchymal transition in DON treatment.

The expression of HMOX1 and SMOX in A549 cells was increased by DON treatment (Fig. 3). HMOX1 encodes an inducible isoform heme oxygenase 1 (HO-1). HO-1 plays an important role in protection from oxidative stress (Agarwal and Bolisetty, 2013). Yang et al. (2014) have reported that in peripheral blood lymphocytes, the expression of HO-1 was significantly increased by DON treatment. Treatment with T-2 toxin, another trichothecene, also induced the expression of HO-1 in the rat fatal brain and dam's liver (Sehata et al., 2004, 2005). Li et al. (2014) indicated that DON induces oxidative stress. In lung epithelia, the expression of $\mathrm{HO}-1$ and protection from oxidative stress are induced by DON treatment. SMOX encodes spermine oxidase (SMO) that catalyses the oxidation of spermine into spermidine, 3 -aminopropanal, and hydrogen peroxide $\left(\mathrm{H}_{2} \mathrm{O}_{2}\right)$. In contrast to $\mathrm{HO}-1$, SMO produces $\mathrm{H}_{2} \mathrm{O}_{2}$ and causes oxidative stress. Although mechanism underlying the induction of SMO remains unknown, HO-1 may be induced to scavenge $\mathrm{H}_{2} \mathrm{O}_{2}$ produced by SMO.

Our study has a limitation; because these genes were partly and transiently transfected to A549 cells, we could not detect significances between vector transfectants and transfectants of interested genes. In further studies, we will examine roles of these genes in DON deleterious effect using stable transfectants.

In conclusion, DON affected the expression of genes with various functions, and the repression of MEIS3 play roles in the deleterious effect of DON in A549 lung epithelial cells.

\section{ACKNOWLEDGMENTS}

We thank Rie Matsuya and Miyu Yamamoto for their technical assistances. This study has been supported by Health and Labour Sciences Research Grants "Research on Food Safety" project (H25-Syokuhin-Wakate-020) of Ministry of Health, Labour and Welfare, Japan. The authors would like to thank Enago (www.enago.jp) for the English language review.

Conflict of interest---- The authors declare that there is no conflict of interest.

\section{REFERENCES}

Agarwal, A. and Bolisetty, S. (2013): Adaptive responses to tissue injury: role of heme oxygenase-1. Trans. Am. Clin. Climatol. Assoc., 124, 111-122.

Amuzie, C.J., Harkema, J.R. and Pestka, J.J. (2008): Tissue distribution and proinflammatory cytokine induction by the trichothecene deoxynivalenol in the mouse: comparison of nasal vs. oral exposure. Toxicology, 248, 39-44.

Amado, M., Almeida, R., Carneiro, F., Levery, S.B., Holmes, E.H., Nomoto, M., Hollingsworth, M.A., Hassan, H., Schwientek, T., Nielsen, P.A., Bennett, E.P. and Clausen, H. (1998): A family of human $\beta 3$-galactosyltransferases: Characterization of four members of a UDP-galactose: $\beta$-N-acetyl-glucosamine/ $\beta$-N-acetylgalactosamine $\beta$-1,3-galactosyltransferase family. J. Biol. Chem., 273, 12770-12778.

Becker, P.M., Tran, T.S., Delannoy, M.J., He, C., Shannon, J.M. and McGrath-Morrow, S. (2011): Semaphorin 3A contributes to distal pulmonary epithelial cell differentiation and lung morphogenesis. PLoS One, 6, e27449.

Behm, C., Föllmann, W. and Degen, G.H. (2012): Cytotoxic potency of mycotoxins in cultures of V79 lung fibroblast cells. J. Toxicol. Environ. Health A, 75, 1226-1231.

Benjamini, Y. and Hochberg, Y. (1995): Controlling the false discovery rate: a practical and powerful approach to multiple testing. J. R. Statist. Soc. B, 57, 289-300.

Brenner, R., Jegla, T.J., Wickenden, A., Liu, Y. and Aldrich, R.W. (2000): Cloning and functional characterization of novel large conductance calcium-activated potassium channel $\beta$ subunits, hKCNMB3 and hKCNMB4. J. Biol. Chem., 275, 6453-6461.

Brera, C., Caputi, R., Miraglia, M., Iavicoli, I., Salerno, A. and Carelli, G. (2002): Exposure assessment to mycotoxins in workplaces: aflatoxins and ochratoxin A occurrence in airborne dusts and human sera. Microchem. J., 73, 167-173.

Cetin, Y. and Bullerman, L.B. (2005): Cytotoxicity of Fusarium mycotoxins to mammalian cell cultures as determined by the MTT bioassay. Food Chem. Toxicol., 43, 755-764.

Creasia, D.A., Thurman, J.D., Jones, L.J.3rd, Nealley, M.L., York, C.G., Wannemacher, R.W.Jr and Bunner, D.L. (1987): Acute inhalation toxicity of T-2 mycotoxin in mice. Fundam. Appl. Toxicol., 8, 230-235.

Creasia, D.A., Thurman, J.D., Wannemacher, R.W. Jr and Bunner, D.L. (1990): Acute inhalation toxicity of T-2 mycotoxin in the rat and guinea pig. Fundam. Appl. Toxicol., 14, 54-59.

Dong, Y., Ikeda, K., Hamamura, K., Zhang, Q., Kondo, Y., Matsumoto, Y., Ohmi, Y., Yamauchi, Y., Furukawa, K., Taguchi, R. and Furukawa, K. (2010): GM1/GD1b/GA1 synthase expression results in the reduced cancer phenotypes with modulation of composition and raft-localization of gangliosides in a melanoma cell line. Cancer Sci., 101, 2039-2047.

Fernandez-Gonzalez, A., Kourembanas, S., Wyatt, T.A. and Mitsialis, S.A. (2009): Mutation of murine adenylate kinase 7 underlies a primary ciliary dyskinesia phenotype. Am. J. Respir. Cell. Mol. 
The expression and the role of MEIS3 in A549 cell on DON treatment

Biol., 40, 305-313.

Food Safety Commission of Japan (2010): Risk Assessment Report Deoxynivalenol and Nivalenol (Mycotoxin).

Guimaraes, C.P., Carette, J.E., Varadarajan, M., Antos, J., Popp, M.W., Spooner, E., Brummelkamp, T.R. and Ploegh, H.L. (2011): Identification of host cell factors required for intoxication through use of modified cholera toxin. J. Cell. Biol., 195, 751-764.

Halstensen, A.S., Nordby, K.C., Klemsdal, S.S., Elen, O., Clasen, P.E. and Eduard, W. (2006): Toxigenic Fusarium spp. as determinants of trichothecene mycotoxins in settled grain dust. J. Occup. Environ. Hyg., 3, 651-659.

Imbeaud, S., Graudens, E., Boulanger, V., Barlet, X., Zaborski, P., Eveno, E., Mueller, O., Schroeder, A. and Auffray, C. (2005): Towards standardization of RNA quality assessment using userindependent classifiers of microcapillary electrophoresis traces. Nucleic Acids Res., 33, e56.

Jiang, Y., Oliver, P., Davies, K.E. and Platt, N., (2006): Identification and characterization of murine SCARA5, a novel class A scavenger receptor that is expressed by populations of epithelial cells. J. Biol. Chem., 281, 11834-11845.

Kralj, A., Gurgui, M., König, G.M. and van Echten-Deckert, G. (2007): Trichothecenes induce accumulation of glucosylceramide in neural cells by interfering with lactosylceramide synthase activity. Toxicol. Appl. Pharmacol., 225, 113-122.

Li, J.Y., Paragas, N., Ned, R.M., Qiu, A., Viltard, M., Leete, T., Drexler, I.R., Chen, X., Sanna-Cherchi, S., Mohammed, F., Williams, D., Lin, C.S., Schmidt-Ott, K.M., Andrews, N.C. and Barasch, J. (2009): Scara5 is a ferritin receptor mediating nontransferrin iron delivery. Dev. Cell, 16, 35-46.

Li, D., Ye, Y., Lin, S., Deng, L., Fan, X., Zhang, Y., Deng, X., Li, Y., Yan, H. and Ma, Y. (2014): Evaluation of deoxynivalenol-induced toxic effects on DF-1 cells in vitro: Cell-cycle arrest, oxidative stress, and apoptosis. Environ. Toxicol. Pharmacol., 37, 141-149.

Liu, J., Wang, Y., Birnbaum, M.J. and Stoffers, D.A. (2010): Threeamino-acid-loop-extension homeodomain factor Meis3 regulates cell survival via PDK1. Proc. Natl. Acad. Sci. USA, 107, 2049420499.

Liu, J., Hu, G., Chen, D., Gong, A.Y., Soori, G.S., Dobleman, T.J. and Chen, X.M. (2013): Suppression of SCARA5 by Snaill is essential for EMT-associated cell migration of A549 cells. Oncogenesis, 2, e73.

Maccioni, H.J., Quiroga, R. and Ferrari, M.L. (2011): Cellular and molecular biology of glycosphingolipid glycosylation. J. Neurochem., 117, 589-602.

Manzanares, D., Srinivasan, M., Salathe, S.T., Ivonnet, P., Baumlin, N., Dennis, J.S., Conner, G.E. and Salathe, M. (2014): IFN- $\gamma$-mediated reduction of large-conductance, $\mathrm{Ca}^{2+}$-activated, voltage-dependent $\mathrm{K}^{+}(\mathrm{BK})$ channel activity in airway epithelial cells leads to mucociliary dysfunction. Am. J. Physiol. Lung Cell. Mol. Physiol., 306, L453-462.

Nielsen, C., Casteel, M., Didier, A., Dietrich, R. and Märtlbauer, E. (2009): Trichothecene-induced cytotoxicity on human cell lines. Mycotoxin Res., 25, 77-84.

Nordby, K.C., Halstensen, A.S., Elen, O., Clasen, P.E., Langseth,
W., Kristensen, P. and Eduard, W. (2004): Trichothecene mycotoxins and their determinants in settled dust related to grain production. Ann. Agric. Environ. Med., 11, 75-83.

Pang, V.F., Lambert, R.J., Felsburg, P.J., Beasley, V.R., Buck, W.B. and Haschek, W.M. (1987) Experimental T-2 toxicosis in swine following inhalation exposure: effects on pulmonary and systemic immunity, and morphologic changes. Toxicol. Pathol., 15, 308-319.

Pang, V.F., Lambert, R.J., Felsburg, P.J., Beasley, V.R., Buck, W.B. and Haschek, W.M. (1988): Experimental T-2 toxicosis in swine following inhalation exposure: clinical signs and effects on hematology, serum biochemistry, and immune response. Fundam. Appl. Toxicol., 11, 100-109.

Pfaffl, M.W. (2001): A new mathematical model for relative quantification in real-time RT-PCR. Nucleic Acids Res., 29, e45.

Schothorst, R.C. and van Egmond, H.P. (2004): Report from SCOOP task 3.2.10 "collection of occurrence data of Fusarium toxins in food and assessment of dietary intake by the population of EU member states." Subtask: trichothecenes. Toxicol. Lett., 153, 133-143.

Schroeder, A., Mueller, O., Stocker, S., Salowsky, R., Leiber, M., Gassmann, M., Lightfoot, S., Menzel, W., Granzow, M. and Ragg, T. (2006): The RIN: an RNA integrity number for assigning integrity values to RNA measurements. BMC Mol. Biol., 7, 3.

Sehata, S., Kiyosawa, N., Makino, T., Atsumi, F., Ito, K., Yamoto, T., Teranishi, M., Baba, Y., Uetsuka, K., Nakayama, H. and Doi, K. (2004) Morphological and microarray analysis of T-2 toxin-induced rat fetal brain lesion. Food Chem. Toxicol., 42, 1727-1736.

Sehata, S., Kiyosawa, N., Atsumi, F., Ito, K., Yamoto, T., Teranishi, M., Uetsuka, K., Nakayama, H. and Doi, K. (2005): Microarray analysis of T-2 toxin-induced liver, placenta and fetal liver lesions in pregnant rats. Exp. Toxicol. Pathol., 57, 15-28.

Shiina, T., Kikkawa, E., Iwasaki, H., Kaneko, M., Narimatsu, H., Sasaki, K., Bahram, S. and Inoko, H. (2000): The $\beta-1,3-$ galactosyltransferase-4 (B3GALT4) gene is located in the centromeric segment of the human MHC class II region. Immunogenetics, 51, 75-78.

Shruti, S., Urban-Ciecko, J., Fitzpatrick, J.A., Brenner, R., Bruchez, M.P. and Barth, A.L. (2012): The brain-specific $\beta 4$ subunit downregulates BK channel cell surface expression. PLoS One, 7, e33429.

Spankie, S. and Cherrie, J.W. (2012): Exposure to grain dust in Great Britain. Ann. Occup. Hyg., 56, 25-36.

Weiger, T.M., Holmqvist, M.H., Levitan, I.B., Clark, F.T., Sprague, S., Huang, W.J., Ge, P., Wang, C., Lawson, D., Jurman, M.E., Glucksmann, M.A., Silos-Santiago, I., DiStefano, P.S. and Curtis, R. (2000): A novel nervous system $\beta$ subunit that downregulates human large conductance calcium-dependent potassium channels. J. Neurosci., 20, 3563-3570.

Yang, W., Yu, M., Fu, J., Bao, W., Wang, D., Hao, L., Yao, P., Nüssler, A.K., Yan, H. and Liu, L. (2014): Deoxynivalenol induced oxidative stress and genotoxicity in human peripheral blood lymphocytes. Food Chem. Toxicol., 64, 383-396. 